\title{
Antimicrobial Resistance Encountered in Garbage Collection Areas and Dumpsites in Nairobi, Kenya Using Escherichia coli and Klebsiella as Indicator Species
}

\author{
Grace Waturu1, Winnie Mutai', John Kiiru², Moses Musyoki', Leonard Ochieng3 \\ ${ }^{1}$ Department of Medical Microbiology, School of Medicine, University of Nairobi, Nairobi, Kenya \\ ${ }^{2}$ Centre of Microbiology Research, Kenya Medical Research Institute, Nairobi, Kenya \\ ${ }^{3}$ Obstetrics and Gynecology Department, School of Medicine, University of Nairobi, Nairobi, Kenya \\ Email: waturug@yahoo.com
}

How to cite this paper: Waturu, G., Mutai, W., Kiiru, J., Musyoki, M. and Ochieng, L. (2017) Antimicrobial Resistance Encountered in Garbage Collection Areas and Dumpsites in Nairobi, Kenya Using Escherichia coli and Klebsiella as Indicator Species. Advances in Microbiology, 7, 653-665. https://doi.org/10.4236/aim.2017.79051

Received: August 3, 2017

Accepted: September 3, 2017

Published: September 6, 2017

Copyright (๑) 2017 by authors and Scientific Research Publishing Inc. This work is licensed under the Creative Commons Attribution International License (CC BY 4.0).

http://creativecommons.org/licenses/by/4.0/

(c) (i) Open Access

\begin{abstract}
Dumpsites and garbage collection areas can act as reservoirs of highly resistant bacterial strains and facilitate the dissemination of Multidrug resistant strains to those living and work on or near the dumpsites and garbage collection areas. The objective of this study was to determine the potential of garbage collection areas and dumpsites in different parts of Nairobi as possible sources of resistant strains using E. coli and Klebsiella as indicator species. The study design was a cross-sectional survey. Sample collection was carried out at different days in seventeen different areas. A total of 126 samples were collected during the sampling period. The samples were then transported to the laboratory for analysis. The samples were cultured on MacConkey agar. Gram staining was done on discrete isolates based on colony characteristics. Biochemical tests were performed on colonies from primary cultures for final identification of the isolates. Antimicrobial disc susceptibility tests and pathogenicity tests were also carried out on the indicator isolates. A total of 121 E. coli and 165 Klebsiella were isolated from all the sampled sites. The highest bacterial burden was recorded from Muthurwa estate dumpsite, with a mean viable count of $8.2 \times 10^{10} \mathrm{cfu} / \mathrm{gm}$ while the least was from Dandora dumpsite with a mean count of $1.1 \times 10^{11} \mathrm{cfu} / \mathrm{gm}$. Overall, gentamicin was the most effective antibacterial agent on Klebsiella and meropenem was the most effective on both E.coli and Klebsiella strains. The isolates showed high resistance to ampicillin, streptomycin, and trimethoprim-sulfamethoxazole. It is concluded that municipal waste dumpsites and garbage collection areas bear heavy burdens of potentially resistant bacteria which may constitute major
\end{abstract}


public health hazards, not only to the immediate communities but also to the families of such site workers.

\section{Keywords}

Dumpsite, Garbage Collection Area, Indicator Organisms, Antimicrobial Resistance

\section{Introduction}

The misuse of antimicrobial agents has been identified as one of the major forces resulting in the rapid spread of resistance, but the nature of this relationship is complex. Resistance to antimicrobials is sometimes brought about by a change in the bacterial genome, which can occur by the transfer of antimicrobial resistance genes which may be found in some of the bacteria found in the environment and transferred to those without the resistance genes and also through other horizontal gene transfer elements [1]. Products that are used in disinfection and sterilization, as well as heavy metals used in industries and households along with antibiotics, creating selective pressure in the environment that lead to mutations in microorganisms [2].

Indiscriminate waste dumping enhances the breeding of microorganisms that pose a danger to the human population. Urban wastes contain a wide range of things that may have come from different sources e.g. hospitals, animal sheds and may carry antimicrobial resistance bacteria belonging to the human and animal commensal flora, mainly Enterobacteriaceae [3]. Waste degradation is enhanced by the presence of soil microorganisms that create a conducive environment for the resistant bacteria e.g. Salmonella species and E. coli to thrive in thus becoming potential human pathogens and may cause severe health hazards [4]. The presence of rodents in these dumpsites and garbage collection areas enhance the spread of antimicrobial resistant bacteria to other areas. Previous studies have focused on the identification of these disease vectors on dumpsites and have reported cockroach, housefly, black garbage fly, and stable fly to be the most prevalent disease vectors on the dumpsites and garbage collection areas [5] [6].

Enterobacteriaceae are one of the major causes of infections and deaths around the world. The prevalence of antimicrobial resistance in this family of bacteria e.g. Escherichia coli, Salmonella and Shigella has raised over the years. One of the major reasons for the increase is the spread of Klebsiella pneumoniae carbapenemase (KPC), a class A serine carbapenemase that was originally isolated from Klebsiella pneumoniae in 1996 [7].

Resistance in pathogenic organisms poses a distinct clinical challenge. However commensal bacteria may enhance the spread of resistant bacteria as they may act as reservoirs of the resistance genes which may have been acquired through various horizontal gene transfer elements. This, therefore, increases the carriage le- 
vels of resistant organisms. The resistant microorganisms from clinical samples may gain their entry into the environment through fecal contamination and various wastes from the hospital that has not been sterilized properly. Escherichia coli and Klebsiella species were used in this study as an indicator species as they are commonly associated with humans and animals disease and have also been used in other studies to gauge the spread of acquired resistance [8].

\section{Materials and Methods}

\subsection{Study Area}

Dumpsites near schools, residential areas and the municipal general waste dumping sites in Nairobi area were selected for the study and sampled. In order to verify the most accessed area of these dumpsites and garbage collection areas by the street families and other people relying on dumpsites for a living, a qualitative survey of the dumpsites and garbage collection areas was conducted. The purpose of the survey was to determine the most appropriate area to sample for the main study. This was done by visiting the dumpsites and garbage collection areas before the start of the study and surveying the areas and identifying potential barriers to our study.

\subsection{Sampling Points}

A total of 17 dumpsites (permanent dumping area) and garbage collection areas (temporary dumping area where garbage is dumped awaiting collection) were randomly sampled in different parts of Nairobi area (Figure 1).



Key: -Dumpsites and garbage Collection areas near residential places; $\nmid$-Dumpsites and garbage Collection areas in Market areas; $\triangle$-Dumpsites and garbage Collection areas near Schools.

Figure 1. Aerial view of sampling sites in Dandora sampling area. 


\subsection{Sample Collection}

Sample collection was randomly carried out in different days in seventeen different points. A total of 126 samples were collected during the sampling period. At each sampling station, the sub-surface soil, mixed solids, leaking water, stagnant water, swabs and food samples were collected from one squire foot area into sterile sampling bottles and appropriately labeled. Six samples were collected from each site. The samples were then transported to the laboratory for analysis.

\subsection{Determination of Microbial Load in the Dumpsites and Garbage Collection Areas}

One gram $(1 \mathrm{~g})$ of each solid samples and $1 \mathrm{~mL}$ of the liquid samples and swabs were suspended in $10 \mathrm{~mL}$ physiological sterile saline. Serial dilutions of 10 fold, 5 fold, and 1 fold dilutions were prepared from the $10 \mathrm{~mL}$ suspension and transferred onto duplicate molten Plate Count Agar (PCA) mixed and allowed to cool at room temperature. This was then incubated at $37^{\circ} \mathrm{C}$ for 24 hours. Colonies were determined from duplicate plates and the average counts recorded as mean viable bacteria (colony forming units [CFUs] of the sample. The low and high CFUs were reached by dividing the dumpsites and garbage collection areas into two, those that had CFUs above 5.0 were considered to be high and those below 5.0 considered being low.

\subsection{Isolation and Identification of E. coli and Klebsiella Species}

A loop full $(1 \mu \mathrm{l})$ of the mixture incubated in buffered peptone water was then transferred onto MacConkey agar plates and incubated at $37^{\circ} \mathrm{C}$ for 24 hours for isolation of E. coli and Klebsiella species. After overnight incubation the plates were then examined for growth and presumptive identification of $E$. coli and Klebsiella species for lactose-fermenting colonies (pink). Presence of pink nonmucoid colonies for $E$. coli and pink mucoid for Klebsiella species were further identified by biochemical tests.

\subsection{Biochemical Identification of the Isolates}

Pure discrete colonies of E. coli and Klebsiella species from primary cultures were identified by gram staining and biochemical tests. Colonies that appeared as gram negative rods were tested for indole test, methyl-red test, VogesProskauer test and citrate utilization (IMViC). Presence of E. coli was interpreted as a positive reaction for indole and methyl-red tests and a negative reaction for Voges-Proskauer test and lack of citrate utilization. Additionally presence of Klebsiella species was interpreted as a negative reaction for indole and methyl-red tests and a positive reaction for Voges-Proskauer test and citrate utilization [9].

\subsection{Antimicrobial Susceptibility Testing}

The antimicrobial susceptibility testing was done on 286 isolates on Mueller- 
Hinton agar plates (Oxoid). The isolates were tested against the following antibiotics; Ampicillin $(10 \mu \mathrm{g})$, Cefpodoxime $(10 \mu \mathrm{g})$, Ceftazidime $(30 \mu \mathrm{g})$, Cefoxitin

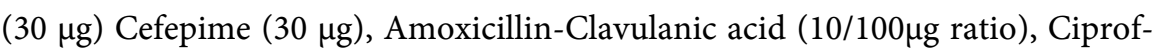
loxacin $(10 \mu \mathrm{g})$, Tetracycline $(30 \mu \mathrm{g})$, Trimethoprim Sulfamethoxazole $(30 \mu \mathrm{g})$, Gentamicin $(10 \mu \mathrm{g})$, Chloramphenicol $(30 \mu \mathrm{g})$, Streptomycin $(25 \mu \mathrm{g})$, Nalidixic acid $(10 \mu \mathrm{g})$, and Meropenem $(10 \mu \mathrm{g})$. The plates were then incubated at $37^{\circ} \mathrm{C}$ for 18 - 24 hours. The inoculums for susceptibility testing were compared against the McFarland 0.5 turbidity standards with E.coli ATCC 25,922 strain being used as the control standard for quality assurance of media and the antimicrobial discs. The interpretation of results was according to Clinical and Laboratory Standards Institute guidelines [10].

\section{Results}

\subsection{Contamination Levels of the Dumpsites and Garbage Collection Areas}

The lowest CFU from any given sampling point was $1.1 \times 10^{11}$ that was recorded in Dandora dumpsite. The site with the highest CFU value was Muthurwa estate dumpsite that recorded $8.2 \times 10^{10}$. Other sites with high CFU counts were Umama garbage collection area (Komarock), Kawangware market dumpsite, Kenyatta staff quarter garbage collection area, Kweria garbage collection area, City market garbage collection area, Central police garbage collection area, Kibera dumpsite, and Kenyatta market dumpsite while Seven of the dumpsites and garbage collection areas (Ayany dumpsite, Dandora dumpsite, Ngara market garbage collection area, Muthurwa market garbage collection area, Masai market dumpsite, Mareba garbage collection area (Kibera), District Commissioner garbage collection area (Kibera) recorded CFUs below $2.0 \times 10^{10}$ Table 1 .

\subsection{Antimicrobial Susceptibility Profile of E. coli and Klebsiella Species}

Resistance pattern to all antimicrobials for E. coli and Klebsiella was above 5\% except for ciprofloxacin (3.3\% E.coli, and $2.4 \%$ Klebsiella), meropenem (1.7\% E.coli and 1.8\% Klebsiella) and gentamicin (3.3\% E.coli and 0\% Klebsiella) Table 2.

\subsection{Antimicrobial Resistance in Dumpsites and Garbage Collection Areas with High and Low Colony Forming Units}

In general, resistances frequencies were similar for E. coli and Klebsiella obtained from samples with high CFUs to those obtained from samples with low CFUs. In the dumpsites and garbage collection areas that had high CFUs, such as Muthurwa estate dumpsite, Central police garbage collection area, City market garbage collection area, City park market dumpsite Figure 2(a), there were high resistance prevalence's of above $25 \%$ to streptomycin, ampicillin, tetracycline and trimethoprim sulfamethoxazole for isolates belonging to both species. 
In contrast, there was low resistance to meropenem, gentamicin, and ciprofloxacin $(\leq 5 \%)$ in both species. The study also found that $42 \%$ of $E$. coli isolates were resistant to ampicillin compared to $59 \%$ of Klebsiella isolates found in this study.

Table 1. Average microbial load of the samples from dumpsites and garbage collection areas and their characteristics.

\begin{tabular}{|c|c|c|c|c|c|}
\hline Dumpsite/garbage collection area & $\begin{array}{l}\text { Area in } \\
\text { Nairobi }\end{array}$ & Location & Average CFUs & $\begin{array}{l}\text { Category } \\
\text { of CFU }\end{array}$ & $\begin{array}{l}\text { Dumpsite/garbage collection } \\
\text { area characteristics }\end{array}$ \\
\hline Muthurwa estate dumpsite & East & Residential & $8.2 \times 10^{10}$ & High & $\begin{array}{l}\text { Fecal contamination, } \\
\text { Domestic/Rodents }\end{array}$ \\
\hline Umama garbage collection area (Komarock) & $\begin{array}{c}\text { North } \\
\text { Western }\end{array}$ & Residential & $7.9 \times 10^{10}$ & High & Seepage, Fecal contamination, \\
\hline Kawangware market dumpsite & East & Market & $7.7 \times 10^{10}$ & High & $\begin{array}{l}\text { Fecal contamination, } \\
\text { Domestic/Rodents }\end{array}$ \\
\hline Kenyatta staff quarter garbage collection area & South & Market & $7.3 \times 10^{10}$ & High & $\begin{array}{c}\text { Seepage, Fecal contamination, } \\
\text { Domestic/Rodents, Human } \\
\text { activity }\end{array}$ \\
\hline Kweria garbage collection area & Central & Residential & $7.2 \times 10^{10}$ & High & $\begin{array}{c}\text { Fecal contamination, } \\
\text { Domestic/Rodents, Human } \\
\text { activity }\end{array}$ \\
\hline City market garbage collection area & Central & Market & $6.7 \times 10^{10}$ & High & seepage, Human activity \\
\hline Central police garbage collection area & West & Residential & $6.1 \times 10^{10}$ & High & Seepage \\
\hline Kibera dumpsite & South & Residential & $5.0 \times 10^{10}$ & High & $\begin{array}{c}\text { Seepage, Fecal contamination, } \\
\text { Domestic/Rodents, Human } \\
\text { activity }\end{array}$ \\
\hline Kenyatta market dumpsite & South & Residential & $5.0 \times 10^{10}$ & High & $\begin{array}{c}\text { Seepage, Fecal contamination, } \\
\text { Domestic/Rodents, Human } \\
\text { activity }\end{array}$ \\
\hline City park market dumpsite & $\begin{array}{c}\text { South } \\
\text { Western }\end{array}$ & Market & $2.0 \times 10^{10}$ & High & $\begin{array}{l}\text { Seepage, Domestic/Rodents, } \\
\text { Human activity }\end{array}$ \\
\hline Muthurwa market garbage collection area & East & Residential & $1.8 \times 10^{11}$ & Low & $\begin{array}{l}\text { Fecal contamination, Human } \\
\text { activity }\end{array}$ \\
\hline Mareba garbage collection area (Kibera) & $\begin{array}{l}\text { South } \\
\text { Eastern }\end{array}$ & School & $1.5 \times 10^{11}$ & Low & $\begin{array}{c}\text { Fecal contamination, } \\
\text { Domestic/Rodents, Human } \\
\text { activity }\end{array}$ \\
\hline Ayany dumpsite & $\begin{array}{l}\text { South } \\
\text { Eastern }\end{array}$ & Residential & $1.5 \times 10^{11}$ & Low & Seepage, Human activity \\
\hline Ngara market garbage collection area & West & Residential & $1.4 \times 10^{11}$ & Low & $\begin{array}{l}\text { Fecal contamination, } \\
\text { Domestic/Rodents }\end{array}$ \\
\hline Masai market dumpsite & West & Market & $1.2 \times 10^{11}$ & Low & Human activity \\
\hline $\begin{array}{l}\text { District Commissioner garbage collection area } \\
\text { (Kibera) }\end{array}$ & South & Residential & $1.2 \times 10^{11}$ & Low & $\begin{array}{l}\text { Seepage, Fecal contamination, } \\
\text { Human activity }\end{array}$ \\
\hline Dandora dumpsite & $\begin{array}{c}\text { North } \\
\text { Western }\end{array}$ & Residential & $1.1 \times 10^{11}$ & Low & $\begin{array}{c}\text { Seepage, Fecal contamination, } \\
\text { Domestic/Rodents, Human } \\
\text { activity }\end{array}$ \\
\hline
\end{tabular}

Key: Seepage-leakage of water into the ground in and around the dumpsite or garbage collection area, Fecal contamination-presences of feces on the dumpsite or garbage collection area, Domestic/Rodents-presence of livestock (e.g. goats) or rodents (e.g. rats) on the dumpsite and garbage collection area, Human activity - presence of humans on or adjacent to the dumpsite and garbage collection area. 
Table 2. Antibiotic susceptibility pattern of E. coli and Klebsiella among the antibiotics tested.

\begin{tabular}{|c|c|c|}
\hline Antimicrobial & E. coli $(\%)$ & Klebsiella (\%) \\
\hline \multicolumn{3}{|c|}{ Ceftazidime (CAZ) } \\
\hline Resistance & $6(5.0)$ & $14(8.5)$ \\
\hline Intermediate & 0 & $3(1.8)$ \\
\hline Susceptible & $115(95.0)$ & $148(89.7)$ \\
\hline \multicolumn{3}{|c|}{ Cefpodoxime (CPD) } \\
\hline Resistance & $24(19.8)$ & $44(26.7)$ \\
\hline Intermediate & $23(19.0)$ & $15(9.1)$ \\
\hline Susceptible & $74(61.2)$ & $106(64.2)$ \\
\hline \multicolumn{3}{|l|}{ Cefoxitin (FOX) } \\
\hline Resistance & $15(12.4)$ & $20(12.1)$ \\
\hline Intermediate & $2(1.7)$ & $1(0.6)$ \\
\hline Susceptible & $104(86.0)$ & $144(87.3)$ \\
\hline \multicolumn{3}{|l|}{ Cefepime (FEP) } \\
\hline Resistance & $16(13.2)$ & $30(18.2)$ \\
\hline Intermediate & $39(32.2)$ & $61(37.0)$ \\
\hline Susceptible & $66(54.5)$ & $74(44.8)$ \\
\hline \multicolumn{3}{|c|}{ Ciprofloxacin (CIP) } \\
\hline Resistance & $4(3.3)$ & $4(2.4)$ \\
\hline Intermediate & $2(1.7)$ & $4(2.4)$ \\
\hline Susceptible & $115(95.0)$ & $157(95.2)$ \\
\hline \multicolumn{3}{|c|}{ Amoxicilin clavulanic acid (AMC) } \\
\hline Resistance & $15(12.4)$ & $19(11.5)$ \\
\hline Intermediate & $18(14.9)$ & $18(10.9)$ \\
\hline Susceptible & $88(72.7)$ & $128(77.6)$ \\
\hline \multicolumn{3}{|l|}{ Tetracycline (T) } \\
\hline Resistance & $33(27.3)$ & $41(24.8)$ \\
\hline Intermediate & $6(5.0)$ & $13(7.9)$ \\
\hline Susceptible & $82(67.8)$ & $111(67.3)$ \\
\hline \multicolumn{3}{|c|}{ Meropenem (MRP) } \\
\hline Resistance & $2(1.7)$ & $3(1.8)$ \\
\hline Intermediate & $19(15.7)$ & $51(30.9)$ \\
\hline Susceptible & $100(82.6)$ & $111(67.3)$ \\
\hline \multicolumn{3}{|l|}{ Streptomycin (S) } \\
\hline Resistance & $55(45.5)$ & $75(45.5)$ \\
\hline Intermediate & $59(48.8)$ & $80(48.5)$ \\
\hline Susceptible & $7(5.8)$ & $10(6.1)$ \\
\hline \multicolumn{3}{|c|}{ Nalidixic acid (NA) } \\
\hline Resistance & $11(9.1)$ & $14(8.5)$ \\
\hline Intermediate & 0 & $2(1.2)$ \\
\hline Susceptible & $110(90.9)$ & $149(90.3)$ \\
\hline \multicolumn{3}{|c|}{ Cloramphenical (C) } \\
\hline Resistance & $7(5.8)$ & $13(7.9)$ \\
\hline Intermediate & $2(1.7)$ & $4(2.4)$ \\
\hline Susceptible & $112(92.6)$ & $148(89.7)$ \\
\hline
\end{tabular}




\section{Continued}

\section{Gentamicin (GEN)}

Resistance
Intermediate
Susceptible

Trimethoprim sulfamethoxazole (SXT)

Resistance
Intermediate
Susceptible

Susceptible

Ampicilin (AMP)

Resistance

Intermediate

Susceptible

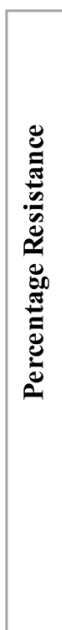

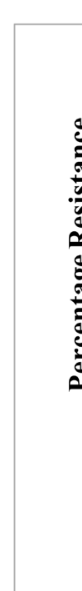

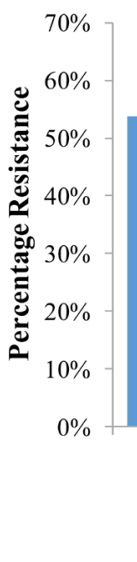

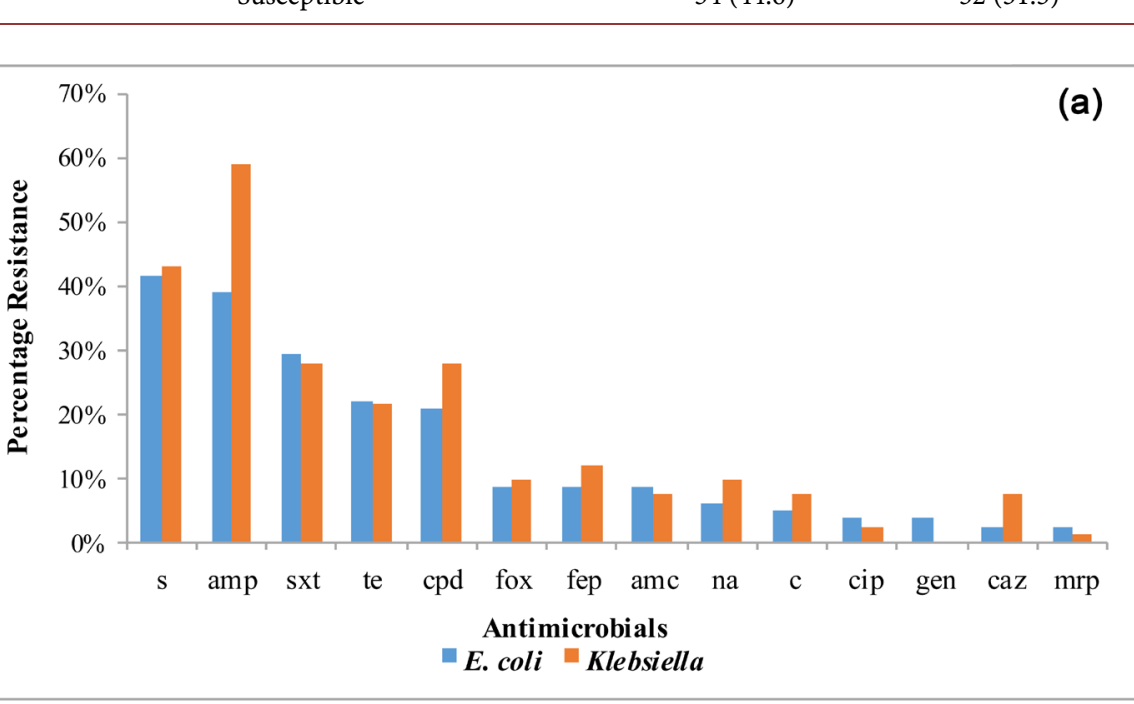

0

$8(4.8)$

$3(2.5)$

$157(95.2)$

$114(94.2)$

$\begin{array}{cc}35(28.9) & 48(29.1) \\ 6(5.0) & 0 \\ 80(66.1) & 117(70.9)\end{array}$

$80(66.1)$

$117(70.9)$

$51(42.1)$

97 (58.8)

$16(13.2)$

$16(9.7)$

54 (44.6)

$52(31.5)$

Key: AMP-ampicillin $(10 \mu \mathrm{g})$, CPD-cefpodoxime $(10 \mu \mathrm{g})$, CAZ-ceftazidime $(30 \mu \mathrm{g})$, FOX-cefoxitin $(30 \mu \mathrm{g}), \mathrm{FEP}$-cefepime $(30 \mu \mathrm{g})$, CIP-ciprofloxacin $(10 \mu \mathrm{g})$, AMC-amoxicillin clavulanic acid $(10 \mu \mathrm{g})$, TE-tetracycline $(30 \mu \mathrm{g}), \mathrm{MRP}-\mathrm{meropenem}(10 \mu \mathrm{g}), \mathrm{S}$-streptomycin $(10 \mu \mathrm{g})$, NA-nalidixic acid $(10$ $\mu \mathrm{g})$, C-chloramphenicol $(10 \mu \mathrm{g})$, GEN-gentamicin $(10 \mu \mathrm{g})$, SXT-trimethoprim sulfamethoxazole (30 $\mu \mathrm{g})$.

Figure 2. (a) antimicrobial resistance in dumpsites and garbage collection areas with high Colony Forming Units, (b) -antimicrobial resistance in dumpsites and garbage collection areas with low Colony Forming Units. 
Resistance to gentamicin among isolates from sites recording high CFUs was only observed for $E$. coli (6\%) while resistance to meropenem from the same population of isolates, was observed in Klebsiella (2.8\%).

There was high resistance (>20\%) to streptomycin, ampicillin, tetracycline, trimethoprim sulfamethoxazole and cefpodoxime for both species in the dumpsites and garbage collection areas that had low CFUs such as the Ngara market garbage collection area, Ayany dumpsite, Dandora dumpsite, Muthurwa market garbage collection area Figure 2(b). In such sites, there was a low resistance of $E$. coli and Klebsiella to meropenem, gentamicin, and ciprofloxacin $(<5 \%)$. The only $E$. coli strains found to be resistant to gentamicin were from the sites with low CFUs.

\subsection{Antimicrobial Resistance Profiles}

The isolates were classified into three resistance profiles (those that were fully susceptible, those resistant to $1-3$ antimicrobials and those resistant to more than 3 antimicrobials (MDROs) as shown in Table 3. There were no isolates that

Table 3. Distribution of isolates with different resistance profiles across dump sites and garbage collection areas.

\begin{tabular}{|c|c|c|c|c|}
\hline \multirow[b]{2}{*}{ Dumpsites/garbage areas } & \multirow[b]{2}{*}{$\begin{array}{l}\text { No. of } \\
\text { isolates }\end{array}$} & \multicolumn{3}{|c|}{$\begin{array}{c}\text { Number of antimicrobials to which } E \text {. coli } \\
\text { and Klebsiella were resistant (\%) }\end{array}$} \\
\hline & & $\begin{array}{c}\text { Fully } \\
\text { susceptible }\end{array}$ & $\begin{array}{l}1-3 \\
\text { antimicrobials }\end{array}$ & $\begin{array}{c}>3 \\
\text { antimicrobials } \\
\text { (MDROs) }\end{array}$ \\
\hline Ayany Dumpsite & 19 & $2(10.5)$ & $10(52.6)$ & $7(36.8)$ \\
\hline Central police garbage collection area & 18 & $1(5.6)$ & $12(66.7)$ & $5(27.8)$ \\
\hline City market garbage collection area & 22 & $3(13.6)$ & $12(54.5)$ & $7(31.8)$ \\
\hline City park Market Dumpsite & 29 & $5(17.2)$ & $20(69.0)$ & $4(13.8)$ \\
\hline Dandora Dumpsite & 33 & $1(3.0)$ & $27(81.8)$ & $5(15.2)$ \\
\hline $\begin{array}{c}\text { District Commissioner's garbage collection } \\
\text { area (Kibera) }\end{array}$ & 9 & 0 & $7(77.8)$ & $2(22.2)$ \\
\hline Kenyatta Market Dumpsite & 15 & $3(20.0)$ & $10(66.7)$ & $2(13.3)$ \\
\hline $\begin{array}{c}\text { Kenyatta staff quarter garbage collection } \\
\text { area }\end{array}$ & 24 & $10(41.7)$ & $13(54.2)$ & $1(4.2)$ \\
\hline Kibera Dumpsite & 15 & 0 & $12(80.0)$ & $3(20.0)$ \\
\hline Kweria garbage collection area & 24 & $3(12.5)$ & $17(70.8)$ & $4(16.7)$ \\
\hline Mareba garbage collection area (Kibera) & 7 & 0 & $4(57.1)$ & $3(42.9)$ \\
\hline Masai Market dumpsite & 14 & 0 & $11(78.6)$ & $3(21.4)$ \\
\hline Muthurwa Estate Dumpsite & 12 & 0 & $4(33.3)$ & $8(66.7)$ \\
\hline Muthurwa Market garbage collection area & 17 & $1(5.9)$ & $10(58.8)$ & $6(35.3)$ \\
\hline Ngara market garbage collection area & 17 & $3(17.6)$ & $12(70.6)$ & $2(11.8)$ \\
\hline Kawangware Market Dumpsite & 4 & 0 & $4(100.0)$ & 0 \\
\hline $\begin{array}{l}\text { Umama garbage collection area } \\
\text { (Komarock) }\end{array}$ & 7 & 0 & $2(28.6)$ & $5(71.4)$ \\
\hline
\end{tabular}

Key: The fully susceptible are those that did not show any resistance while resistance is showing resistance to 1-3 antimicrobials and MDROs are those that show resistance to more than 3 antimicrobials. 
were fully susceptible in 7 (41\%) of the seventeen dumpsites and garbage collection areas sampled. Most (61\%) of the isolates were resistant to 1 - 3 antimicrobials. Another $23 \%$ of isolates were resistant to more than 3 antimicrobials and were thus multidrug resistant (MDROs). In the Umama garbage collection area (Komarock) 5 (71\%) out of the 7 isolates recovered, were MDROs but no MDROs strain was recovered from the Kawangware market dumpsite. The sites with the highest prevalence of MDROs strains included Muthurwa estate dumpsite (66\%) and Umama garbage collection area (Komarock) (71\%) that both recorded high CFUs as well as shown earlier in Table 1.

\section{Discussion}

Based on the qualitative survey, this study showed that there was evidence of human contact with garbage and dumpsites surveyed. Some of these sites had high CFUs indicating a high possibility of contamination with fecal material. It is, therefore, possible that these interactions pose a serious danger to the public who work and sell their salvaged merchandise from such sites. Such merchandise may include fruits and vegetables. This may result in the spread of pathogens to the unsuspecting public. These results are in agreement with a study done in Nigeria that found that waste scavenging poses a great threat to the public. In addition, such dumpsites allow the growth of many pathogenic bacteria including those that may be MDR [11]. Human and animal scavengers were invariably at the site at all times.

This study's results show that the mean colony counts obtained from the dumpsite and garbage collection areas in residential areas and market places close to the dumpsite were relatively high. Among the dumpsites and garbage collection areas that had high CFUs, $70 \%$ were found in residential areas and $20 \%$ in market areas. In the dumpsites and garbage collection areas that had low CFUs, $57 \%$ were in residential areas and $14 \%$ in market areas. These high CFUs were probably as a result of the presence of fecal contamination and human activity in the dumpsites and garbage collection areas. The results obtained in this study correlates with that of Odeyemi, 2012 that showed that the mean total bacterial counts obtained from the dumpsite and in the residential area are relatively higher than those obtained at neighbouring streams or samples collected at least $50 \mathrm{~m}$ away from dumpsites [12]. This shows how fast resistant bacteria from the environment can gain entry into the human body through contamination from these dumpsites and garbage collection areas, thus creating high health concerns in the public health sector. It is also worthy of note that the heaviest bacteria burden in this study was found at Muthurwa estate dumpsite and that the least was at Dandora dumpsite. This may not be too surprising since Muthurwa estate dumpsite had fecal contamination and a high number of trespassers thus bringing and taking a high number of the bacteria with them. Dandora dumpsite was the only dumpsite with a structured management system. This is the largest dumpsite in East and Central Africa, where rubbish/garbage 
from different parts of the city is dumped. This potentially offers a chance of transfer of pathogens from such sites to human residential sites since Dandora dumpsite is closely located to an ever busy residential area.

This present study also determined antibiotic resistance profile of $E$. coli and Klebsiella from the sampled sites. A high proportion of E. coli and Klebsiella strains were resistant to ampicillin (42\%,59\%), streptomycin (46\%, 46\%) and trimethoprim/sulfamethoxazole $(29 \%, 29 \%)$ respectively. While these values may be lower than those reported from clinical studies [13] These results suggest that resistance to antimicrobials is rising and this may be due to either the intrinsic resistance of many microorganisms to antibiotics or acquired resistance of the organisms enabled by the transfer of resistance of drug resistance plasmids. A high level of resistance has been found with members of the family Enterobacteriaceae which are increasingly becoming MDR. The origin of this resistance can probably be traced to the fecal constituent of the wastes or dump produced by people or animals that have been treated indiscriminately with various antibiotics and also to antibiotics production naturally by soil microorganisms [14]. The resistance prevalence of the two species was almost similar in all the antimicrobials used in this study. This indicates that the action of the antimicrobial to the two species works in an almost similar way thus the close resistance prevalence.

The highest multidrug resistance was found in Umama garbage collection area (71\%), and the lowest multidrug resistance was found in Kenyatta staff quarter garbage collection area (4\%). This difference may be due to the difference in diversity of dumpsites and garbage content and possible difference in the amount of human and animal fecal contaminants in different sites. Some sites recorded an MDR prevalence of more than $50 \%$ indicating that resistance to antimicrobials is on the rise and thus may lead to an increase in resistance related complications. The presence of high MDR phenotypes among environmental samples is an indication that resistant clinical samples are gaining entry into these sites. The possible factors driving the emergence of MDR phenotype could be the poor use of combined therapy.

\section{Conclusion}

Poor waste disposal and recycling practices are still rampant across the dumpsites and garbage collection areas. From the study, there was a high occurrence of Klebsiella and E. coli across the dumpsites and garbage collection areas indicating environmental contamination. Most of the dumpsites and garbage collection areas with high CFUs were found in residential areas indicating that contamination of the dumpsites and garbage collection areas maybe on the rise due to human interference. Isolates from dumpsites and garbage collection areas were resistant to a high proportion of the antimicrobials tested. This shows that clinical bacterial strains are gaining access into the environment thus the high resistance prevalence. The most effective antimicrobial was gentamicin to E. coli and 
meropenem to both isolates. The most non-effective antimicrobials were ampicillin and streptomycin indicating that the future of the antimicrobials is at risk with the changing bacterial pressure. A high frequency of MDR isolates was recorded in the garbage collection areas than in dumpsites. These findings concluded that human activities during collection of the garbage could play a role in the contamination of the dumpsites with potential clinical isolates which can help spread antimicrobial resistance to the environmental strains.

\section{Acknowledgements}

Grateful acknowledgement is expressed to my able supervisors Ms. Winnie Mutai and Dr. John Kiiru for their continuous efforts towards making this study a reality. Few, if any, projects are written without the support and professional contributions of many people. This work is no exception. I admired my supervisors' patience, enthusiasm, motivation and immense knowledge they imparted to me during this period. They have guided me in the time of research and writing of this thesis.

\section{Ethical Approval}

Approved.

\section{Authors Contribution}

GW wrote the proposal and drafted the manuscript. She also did the lab work throughout the study. Ms. WM assisted in the cleanup of the proposal, drafting, and submission of the manuscript. Dr. Kiiru also assisted in the cleanup of the proposal and supervision of the laboratory work. Mr. MM and LO assisted in the laboratory and statistical analysis. All the authors read and approved the manuscript.

\section{Authors Information}

GW is a master's student at the University of Nairobi Medical Microbiology department. Miss. WM is a lecturer at the University of Nairobi Medical microbiology department who has vast experience in proposal presentation, writing, and microbial techniques. Dr. JK guided through the study and he is a senior researcher at the Kenya Medical Research Institute. MM and LO are graduate assistants working with the University of Nairobi who have a wealth of experience in laboratory research and data analysis.

\section{References}

[1] Ignatius, M. (2007) Isolation, Antibiotic and Heavy Metal Susceptibility Patterns of Some Pathogens from Domestic Dumpsites and Waste Water. Master's Thesis, Ahmadu Bello University, Zaria.

[2] Baquero, F., Negri, M.C., Morosini, M.I. and Blázquez, J. (1998) Antibiotic-Selective Environments. Clinical Infectious Diseases, 27, 5-11. https://doi.org/10.1086/514916 
[3] Goñi-urriza, M., Capdepuy, M., Arpin, C., Raymond, N., Caumette, P. and Quentin, C. (2000) Impact of an Urban Effluent on Antibiotic Resistance of Riverine Enterobacteriaceae Impact of an Urban Effluent on Antibiotic Resistance of Riverine Enterobacteriaceae and Aeromonas spp . Applied and Environmental Microbiology, 66, 125-132. https://doi.org/10.1128/AEM.66.1.125-132.2000

[4] Wachukwu, C.K., Mbata, C.A. and Nyenke, C.U. (2010) The Health Profile and Impact Assessment of Waste Scavengers (Rag Pickers) in Port Harcourt, Nigeria. Journal of Applied Sciences, 10, 1968-1972. https://doi.org/10.3923/jas.2010.1968.1972

[5] Mwaikono, K.S., Maina, S., Sebastian, A., Schilling, M., Kapur, V. and Gwakisa, P. (2016) High-Throughput Sequencing of 16S rRNA Gene Reveals Substantial Bacterial Diversity on the Municipal Dumpsite. BMC Microbial. BMC Microbiology, 16, 1-12. https://doi.org/10.1186/s12866-016-0758-8

[6] Ahmed, A. (2011) Insect Vectors of Pathogens in Selected Undisposed Refuse Dumps in Kaduna Town. The Scientific World Journal, 6, 21-26.

[7] Gonzalo, X. and Drobniewski, F. (2013) Is There a Place for Beta-Lactams in the Treatment of Multidrug-Resistant/Extensively Drug-Resistant Tuberculosis? Synergy between Meropenem and Amoxicillin/Clavulanate. Journal of Antimicrobial Chemotherapy, 68, 366-369. https://doi.org/10.1093/jac/dks395

[8] Hellweger, F.L., Ruan, X. and Sanchez, S. (2011) A Simple Model of Tetracycline Antibiotic Resistance in the Aquatic Environment (with Application to the Poudre River). International Journal of Environmental Research and Public Health, 8, 480-497. https://doi.org/10.3390/ijerph8020480

[9] Cheesbrough, M. (2006) District Laboratory Practice in Tropical Countries. Part 2. Tropical Health Technology, Cambridge. https://doi.org/10.1017/CBO9780511543470

[10] CLSI (2016) CLSI 2016 Antimicrobial Susceptibility Testing Guideline. CLSI, Location, 950.

[11] Odeyemi, A. (2012) Antibiogram Status of Bacterial Isolates from Air around Dumpsite of Ekiti State Destitute Centre at Ilokun, Ado-Ekiti, Nigeria. Journal of Microbiology Research, 2, 12-18. https://doi.org/10.5923/j.microbiology.20120202.03

[12] Odeyemi, A. (2012) Antibiogram Status of Bacterial Isolates from Air around Dumpsite of Ekiti State Destitute Centre at Ilokun, Ado-Ekiti, Nigeria. Journal of Microbiology Research, 2, 12-18.

http://article.sapub.org/10.5923.j.microbiology.20120202.03.html https://doi.org/10.5923/j.microbiology.20120202.03

[13] Njoroge, S. (2015) Phenotypic and Genotypic Resistance Patterns among Fecal E. coli Isolated from Severely Malnourished and Non-Malnourished Children Attending Mbagathi District Hospital, Nairobi. Master's Thesis, Kenyatta University, Kahawa.

[14] Ajayi, A. and Akonai, K.A. (2003) Antibiotic Sensitivity Profile of Microorganisms Encountered. African Journal of Biomedical Research, 6, 79-84. 
Submit or recommend next manuscript to SCIRP and we will provide best service for you:

Accepting pre-submission inquiries through Email, Facebook, LinkedIn, Twitter, etc. A wide selection of journals (inclusive of 9 subjects, more than 200 journals)

Providing 24-hour high-quality service

User-friendly online submission system

Fair and swift peer-review system

Efficient typesetting and proofreading procedure

Display of the result of downloads and visits, as well as the number of cited articles Maximum dissemination of your research work

Submit your manuscript at: http://papersubmission.scirp.org/

Or contact aim@scirp.org 